\title{
Wpływ zawartości gazów na właściwości złączy blach ze stopu tytanu grade 12 spawanych metodą TIG
}

\section{The influence of content of gases on properties of titanium grade 12 TIG welded joints}

\section{Streszczenie}

W artykule przedstawiono właściwości mechaniczne, fizyczne i plastyczne oraz przykłady zastosowań wybranych gatunków tytanu i stopów tytanu. Zbadano zawartości azotu, tlenu i wodoru w złączach spawanych i materiale podstawowym ze stopu tytanu Ti0,7Ni0,3Mo (grade 12). Przedstawiono główne źródła zanieczyszczeń jeziorka metalu przez azot, tlen i wodór oraz ich wpływ na właściwości mechaniczne złącza. Omówiono sposoby zapobiegania przed dostępem azotu, wodoru i tlenu do jeziorka spawalniczego.

\section{Wstęp}

Tytan należy do metali często występujących w skorupie ziemskiej. Pomimo to tytan jest stosunkowo drogi, z uwagi na problemy z otrzymywaniem go w czystej postaci, co jest związane $z$ wysoką jego reaktywnością.

Do głównych zalet tytanu można zaliczyć najkorzystniejszy stosunek masy do wytrzymałości oraz wysoką odporność na środowiska korozyjne, np.: wodę morską, zasady, kwasy organiczne, chlor w postaci gazowej i rozcieńczone kwasy: solny i siarkowy. Tytan bardzo szybko jest roztwarzany przez stężone kwasy nieorganiczne, szczególnie kwas azotowy czy fluorowodorowy $[1 \div 6]$.

Mgr inż. Łukasz Mazur, IWE, mgr inż. Aleksander Warsz, IWI - WAREXIM, Gliwice.

\section{Abstract}

The mechanical, physical and plastic properties as well as application examples of selected titanium and titanium alloys grades were introduced in this paper. Content of nitrogen, oxygen and hydrogen in weld joint and parent metal of $\mathrm{Ti} 0,7 \mathrm{Ni} 0,3 \mathrm{Mo}$ titanium alloy were measured. Main sources of gases like nitrogen, oxygen and hydrogen as contamination of weld pool causing lowering of mechanical properties were discussed. Preventing method against of introducing gases like nitrogen, hydrogen and oxygen into weld pool were discussed.
Przykłady zastosowań tytanu w technice przedstawiono na rysunku 1. Mimo wysokiej ceny szczególne zastosowanie znalazł on w przemyśle kosmicznym i lotniczym, m.in. do produkcji wahadłowców i silników odrzutowych.

Ze względu na niższą od stali nierdzewnej i niklu gęstość oraz brak powodowania jakichkolwiek reakcji alergicznych i dobrą tolerancję przez żywe organizmy tytan znalazł zastosowanie $w$ medycynie do produkcji implantów medycznych, endoprotez, a także w jubilerstwie (rys. 2, 3).

$\mathrm{Na}$ uwagę zasługuje również możliwość barwienia tytanu oraz uzyskiwania szerokiej gamy kolorów, co nadaje elementom wykonanym z tytanu atrakcyjny wygląd (rys. 3). Kolory, jakie powstają na powierzchni tytanu, stanowią również istotną informację dla spawalników. O występowaniu konkretnej barwy decyduje grubość warstwy tlenkowej, która zależy od czasu i temperatury wytrzymania tytanu $\mathrm{w}$ atmosferze powietrza $[1 \div 3]$. 

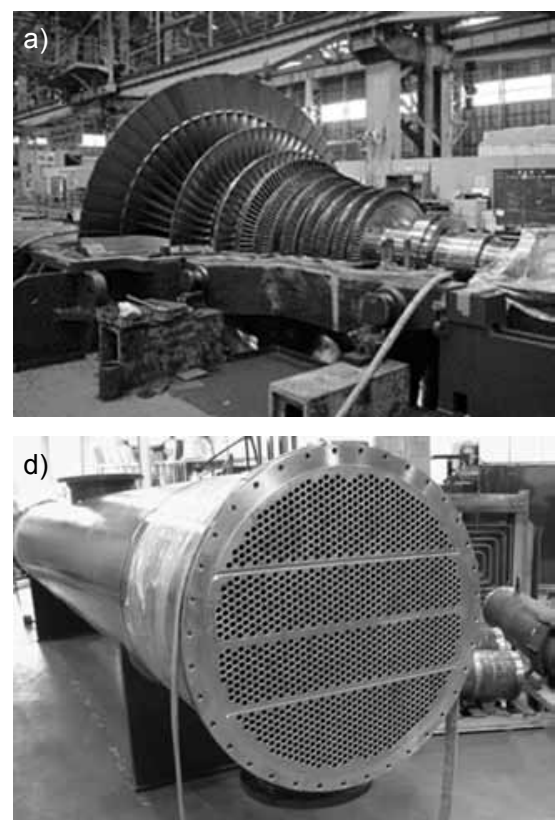
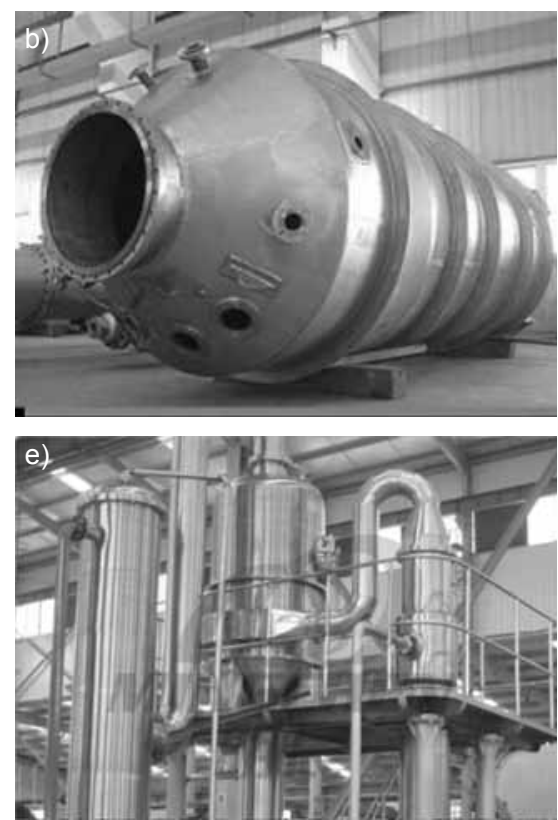

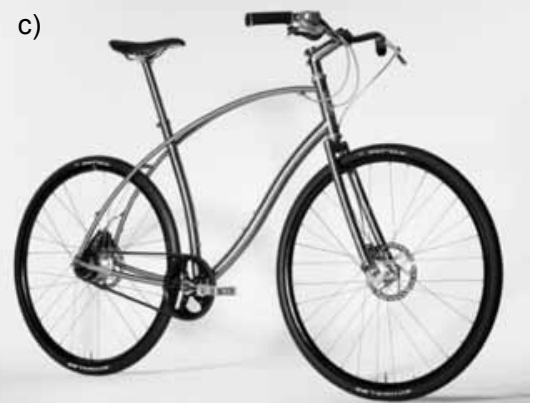

f)

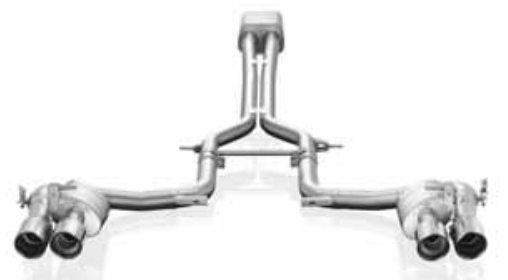

Rys. 1. Przykłady zastosowań tytanu: a) łopatki turbiny, b) zbiornik ciśnieniowy, c) rama rowerowa, d) wymiennik ciepła, e) wyparka z wymu-

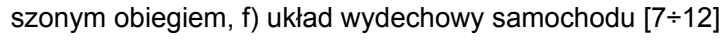

Fig. 1. Examples of application of titanium: a) turbine blade, b) pressure vessel, c) bicycle frame, d) heat exchanger, e) evaporator with

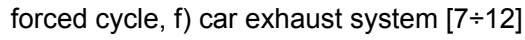

a)
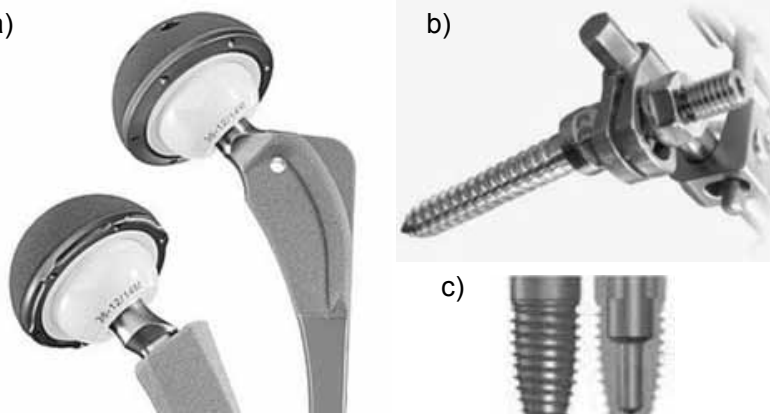

c)

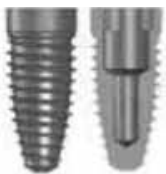

Rys. 2. Przykłady zastosowania tytanu w medycynie: a) endoproteza długotrzpieniowa stawu biodrowego, b) implant kręgosłupa, c) im-

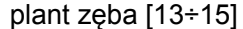

Fig. 2. Examples of titanium application in medicine: a) double-arbor

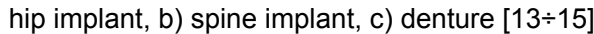
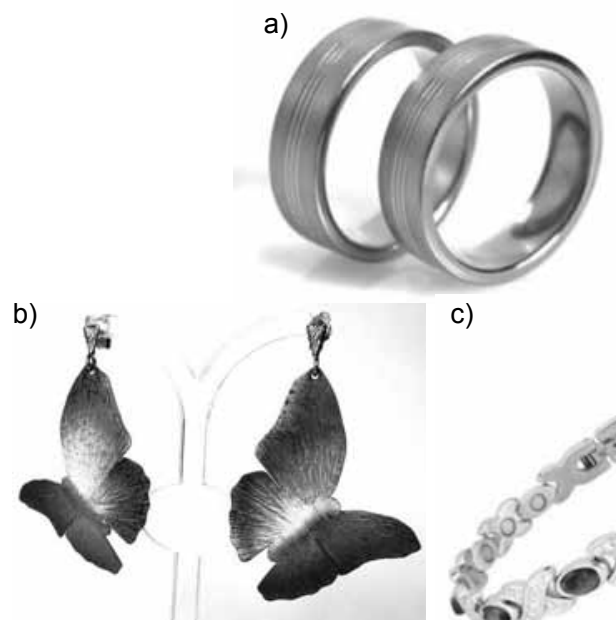

c)

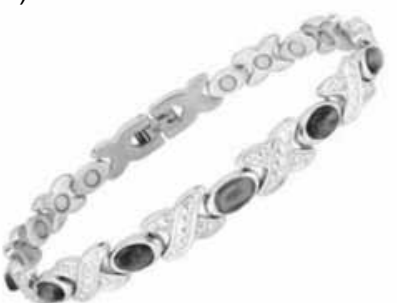

Rys. 3. Przykłady zastosowań tytanu w jubilerstwie: a) obrączki, b) kolczyki, c) bransoleta [16 $\div 18]$

Fig. 3. Examples of titanium application in jewellery: a) rings, b) earrings, c) bracelet $[16 \div 18]$

\section{Porównanie właściwości tytanu i innych materiałów}

Czysty tytan (grade 1) charakteryzuje się niższymi właściwościami mechanicznymi niż stale: niskowęglowa S235JR i nierdzewna X2CrNi-18-10. Wzrost wytrzymałości tytanu następuje wraz ze zwiększeniem ilości tlenu i żelaza (gatunki grade $2 \div 4$ ), jednocześnie jednak zmniejszeniu ulegają właściwości plastyczne.

Stopy tytanu mają bardzo wysokie właściwości, zarówno plastyczne, jak i wytrzymałościowe. Wytrzymałość na rozciąganie stopów tytanu sięga nawet $1500 \mathrm{MPa}$ (tabl. I). Dlatego podczas spawania połączeń z tytanu należy zachować szczególną ostrożność, aby ograniczyć zawartość tlenu w spoinach.

Tytan odznacza się niską przewodnością cieplną zdecydowanie niższą od przewodności aluminium oraz stali niskowęglowej. Przewodność cieplna tytanu grade $1 \div 4$ jest na podobnym poziomie jak stali nierdzewnej. W przypadku stopów tytanu przewodność cieplna jest jeszcze niższa (tabl. I). Ze względu na właściwości fizyczne i wysoką reaktywność, podczas spawania tytanu występują trudności z uzyskaniem odpowiedniej głębokości wtopienia, wymaganych właściwości plastycznych, a także problemy związane $z$ łatwo utleniającą się powierzchnią spoiny lub strefy wpływu ciepła. Należy więc unikać zwiększania głębokości wtopienia przez podnoszenie parametrów prądowo-napięciowych. Wzrost mocy łuku może spowodować zaburzenie osłony gazowej oraz nadmierne nagrzanie lub nawet przegrzanie, a wiec - wzrost zawartości gazów w spoinie $[1 \div 6,19 \div 24]$. 
Tablica I. Właściwości wytrzymałościowe wybranych stali, aluminium oraz tytanu i stopów tytanu $[19 \div 24]$

Table I. Mechanical properties of selected steels, aluminium, tita-

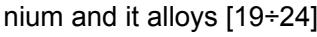

\begin{tabular}{|c|c|c|c|c|c|}
\hline Oznaczenie & $\begin{array}{c}\text { Grani- } \\
\text { ca pla- } \\
\text { styczno- } \\
\text { ści } \\
\mathrm{MPa}\end{array}$ & $\begin{array}{c}\text { Wytrzy- } \\
\text { małość } \\
\text { na roz- } \\
\text { ciąganie } \\
\mathrm{MPa}\end{array}$ & $\begin{array}{c}\text { Wydłu- } \\
\text { żenie } \\
\%\end{array}$ & $\begin{array}{c}\text { Gęstość } \\
\text { g/cm }\end{array}$ & $\begin{array}{c}\text { Prze- } \\
\text { wod- } \\
\text { ność } \\
\text { cieplna } \\
\text { W/mK }\end{array}$ \\
\hline S235JR & 235 & 360 & 22 & 7,81 & 50 \\
\hline X2CrNi18-9 & 220 & 520 & 45 & 7,90 & 15,0 \\
\hline Al 99,5 & 20 & 65 & 20 & 2,7 & 237 \\
\hline $\begin{array}{c}\text { Tytan grade 1 } \\
\text { Ti 99,8 }\end{array}$ & 170 & 240 & 24 & 4,51 & 16,0 \\
\hline $\begin{array}{c}\text { Tytan grade 2 } \\
\text { Ti 99,6 }\end{array}$ & 275 & 345 & 20 & 4,51 & 16,4 \\
\hline $\begin{array}{c}\text { Tytan grade 3 } \\
\text { Ti 99,5 }\end{array}$ & 360 & 480 & 18 & 4,50 & 19,9 \\
\hline $\begin{array}{c}\text { Tytan grade 4 } \\
\text { Ti 99,3 }\end{array}$ & 500 & 600 & 15 & 4,51 & 17,2 \\
\hline $\begin{array}{c}\text { Tytan grade 12 } \\
\text { Ti0,7Ni0,3Mo }\end{array}$ & 345 & 483 & 18 & 4,50 & 19,0 \\
\hline \begin{tabular}{c} 
Ti-6Al-4V \\
\hline Ti-3Al-8V-6Cr- \\
4Mo-4Zr
\end{tabular} & 1420 & 1500 & 8 & 4,82 & 6,2 \\
\hline
\end{tabular}

Tablica II. Zawartość gazów w tytanie grade 1 $\div 5$ oraz grade 12 [20] Table II. Content of gases in titanium grade $1 \div 5$ and grade 12 [20]

\begin{tabular}{|c|c|c|c|c|c|}
\hline \multirow{2}{*}{ Oznaczenie } & \multicolumn{5}{|c|}{ Skład chemiczny, \% } \\
\cline { 2 - 6 } & $\mathrm{O}_{2}$ & $\mathrm{~N}_{2}$ & $\mathrm{H}_{2}$ & $\mathrm{Fe}$ & Inne \\
\hline Ti 99,8 & 0,18 & 0,03 & 0,015 & 0,2 & - \\
\hline Ti 99,6 & 0,25 & 0,03 & 0,015 & 0,3 & - \\
\hline Ti 99,5 & 0,35 & 0,05 & 0,015 & 0,5 & - \\
\hline Ti 99,3 & 0,40 & 0,05 & 0,015 & 0,4 & - \\
\hline Ti-6Al-4V & 0,20 & 0,05 & 0,015 & 0,4 & $5,5-6,75 \mathrm{Al} ; 3,5-4,5 \mathrm{~V}$ \\
\hline Ti0,7Ni0,3Mo & 0,25 & 0,03 & 0,015 & 0,3 & $0,6-0,9 \mathrm{Ni} ; 0,2-0,4 \mathrm{Mo}$ \\
\hline
\end{tabular}

\section{Wpływ tlenu, azotu i wodoru na właściwości tytanu i jego stopów}

Gazy takie jak wodór, tlen i azot wywierają ogromny wpływ na właściwości tytanu i jego stopów. Ich zawartość może być zwiększona już na etapie produkcji, przez zastosowanie niewłaściwych parametrów procesu. W przypadku łączenia tytanu z wykorzystaniem metod spawalniczych zawartość gazów może się niebezpiecznie zwiększyć, na przykład wskutek zastosowania niedostatecznej osłony gazowej lub niewłaściwej technologii spawania. Największa prędkość dyfuzji tlenu, azotu i wodoru występuje w stopach tytanu $\alpha$, o strukturze heksagonalnej zwartej.

Podczas oddziaływania wysokiej temperatury (spawanie, obróbka cieplna), szczególnie w temperaturze powyżej $550^{\circ} \mathrm{C}$, tlen dyfunduje w głąb materiału. W warstwach wierzchnich wskutek wysokiego powinowactwa tworzą się tlenki tytanu $\mathrm{TiO}_{2}$, a w głębi materiału tlen

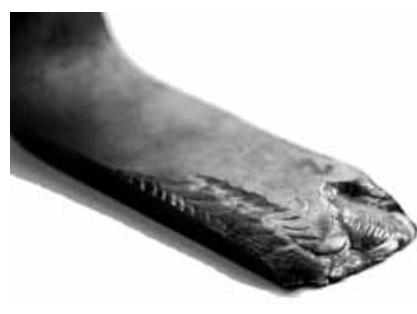

Rys. 4. Nalot powstały podczas niewłaściwego wykonywania próbek stopiwa $z$ tytanu

Fig. 4. Heat tint in incorrect properties of titanium weld metal samples

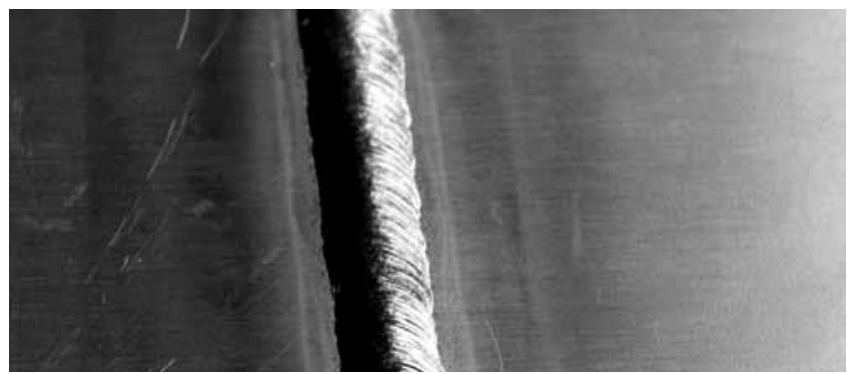

Rys. 5. Powierzchnia złącza spawanego z tytanu pokryta azotkiem tytanu

Fig. 5. The view of welded joint surface with visible titanium nitride
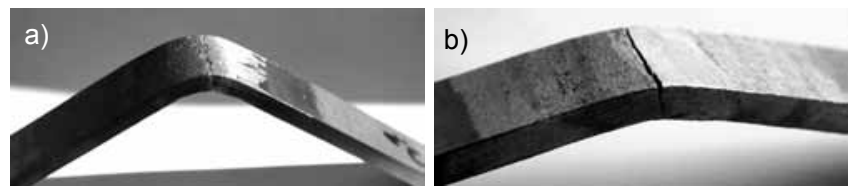

Rys. 6. Pęknięcia w próbie gięcia złącza spawanego z blach tytanowych grade 12 (o grubości $6 \mathrm{~mm}$ ): a) kąt gięcia $25^{\circ}$, b) kąt gięcia $15^{\circ}$ Fig. 6. Cracks in bending test of titanium grade 12 plates $(6 \mathrm{~mm}$ thickness): a) bending angle $25^{\circ}$, b) bending angle $15^{\circ}$

występuje w postaci dyfundującej. Wskutek dobrej rozpuszczalności tlenu w tytanie, przy powierzchni materiału jego zawartość może osiągać $14,5 \%$, powodując powstanie ciagłych warstewek tlenku tytanu. Warstwy te charakteryzują się wysoką twardością, odpornością na ścieranie oraz niską plastycznością (tabl. I, II). W blachach tytanowych, których powierzchnia została nasycona tlenem, próba gięcia najczęściej kończy się wynikiem negatywnym, z powodu właściwości warstwy tlenku tytanu (rys. 4). Grubość warstwy utlenionej zależy od dostępu do tlenu oraz temperatury i czasu ekspozycji $[1 \div 3,25 \div 29]$.

Azot charakteryzuje się wysokim powinowactwem chemicznym do tytanu, większym niż tlen. Powstałe azotki można łatwo rozpoznać po złotym przebarwieniu powierzchni podczas spawania lub obróbki cieplnej (rys. 5). Azotki tytanu charakteryzują się bardzo dużą twardością, do ok. $2400 \mathrm{HV}$, a więc niską plastycznością i udarnością. Zwiększona zawartość azotu w blachach $z$ tytanu oraz złączach powoduje niebezpieczństwo powstawania pęknięć podczas formowania na zimno, spawania sztywnych konstrukcji i próby gięcia $[25 \div 29]$.

W czystym tytanie oraz w stopach tytanu o strukturze $\alpha$ tlen i azot pełnią rolę stabilizatorów fazy a i jednocześnie, wraz ze wzrostem zawartości tych pierwiastków, wzrasta wytrzymałość. Jednak wskutek utwardzenia roztworowego maleją udarność i przewężenie. Podczas produkcji blach z tytanu i jego stopów oraz w czasie 
spawania dąży się do ograniczenia zawartości wodoru do poziomu poniżej 200 ppm (200 cząstek na milion). Wodór należy do gazów bardzo łatwo pochłanianych przez tytan, a zwłaszcza przez Tia. Adsorpcja, absorpcja i dyfuzja wodoru przez tytan zaczyna się w temperaturze powyżej $150^{\circ} \mathrm{C}$, pochłanianie wodoru przez tytan jest intensywne w $320^{\circ} \mathrm{C}$, natomiast w $500^{\circ} \mathrm{C}$ stan nasycenia, zgodnie z warunkami równowagi, może być osiągnięty w ciągu kilku sekund.

W odróżnieniu od azotu czy tlenu, wodór nie powoduje umocnienia tytanu. Głównym powodem obniżenia się plastyczności tytanu nie jest rozpuszczony wodór, lecz występująca w temperaturze otoczenia faza międzywęzłowa $\gamma\left(\mathrm{TiH}_{2}\right)$, o sieci regularnej przestrzennie centrycznej. Faza $\gamma$ wydziela się w lukach oktaedrycznych sieci A3.

Znaczne rozpuszczenie wodoru w tytanie podczas produkcji lub spawania, a następnie wydzielenie fazy $\gamma$ jest przyczyną spadku udarności i wydłużenia, zwiększenia się kruchości i skłonności do pękania. Dodatkowo podczas przemian strukturalnych, zachodzących wskutek oddziaływania cyklu cieplnego spawania, generowane są wysokie naprężenia, które umacniają spawany materiał, powodując spadek jego właściwości plastycznych. Efektem zachodzących przemian mogą być pęknięcia, powstające podczas spawania lub zwłoczne, oraz pękanie podczas formowania na zimno lub próby gięcia złącza spawanego (rys. 6) [25, 26, 30, 31].

W przypadku wodoru, w odróżnieniu od tlenu i azotu, możliwe jest obniżenie jego zawartości, ponieważ wodór z czasem może wydyfundować z metalu. Proces dyfuzji można przyspieszyć, wygrzewając złącze w wysokiej temperaturze w atmosferze ochronnej, np. argonowej, im dłuższy czas wygrzewania, tym więcej wodoru może wydyfundować ze złącza [25, 30, 31].

\section{Badanie ilości gazów w materiale dodatkowym i podstawowym}

Do badań zastosowano stop tytanu Ti-0,3Mo-0,8Ni (tytan grade 12) oraz spoiwo Ti3401. Analizę ilościową gazów, takich jak $\mathrm{H}_{2}, \mathrm{O}_{2}$ i $\mathrm{N}_{2}$, przeprowadzono metodą ekstrakcji na gorąco. Próbki z materiałów podstawowych zostały pobrane do badań z głębokości do $1 \mathrm{~mm}$. Próbki do badania stopiw wykonano zgodnie z PN-EN 6847 [33]. Materiał do analizy zawartości gazów w stopiwach został pobrany z napoin, z głębokości do $3 \mathrm{~mm}$. Wyniki badań przedstawiono $w$ tablicach III i IV.

Tablica III. Zawartość gazów w próbkach z materiału podstawowego z różnych wytopów oraz wyniki próby gięcia (tabl. II)

Table III. Gases content in the samples of different base material melt (tab. II)

\begin{tabular}{|c|c|c|c|c|c|}
\hline \multirow{2}{*}{$\begin{array}{c}\mathrm{Nr} \\
\text { próbki }\end{array}$} & \multicolumn{3}{|c|}{ Zawartość gazów, \% } & \multirow{2}{*}{ Uwagi } & \multirow{2}{*}{ Wynik próby gięcia* } \\
\cline { 2 - 4 } & $\mathrm{O}_{2}$ & $\mathrm{~N}_{2}$ & $\mathrm{H}_{2}$ & & \\
\hline 1 & 0,19 & 0,0069 & 0,0026 & wytop nr 1 & pozytywny \\
\hline 2 & 0,20 & 0,0154 & 0,0037 & wytop nr 2 & pozytywny \\
\hline \multicolumn{7}{|c}{ Próbę gięcia przeprowadzono zgodnie z PN-EN ISO 15614-5 } \\
\hline
\end{tabular}

Tablica IV. Zawartość gazów w próbkach ze stopiwa

Table IV. Gases content in weld metal samples

\begin{tabular}{|c|c|c|c|c|c|}
\hline \multirow{2}{*}{$\begin{array}{c}\mathrm{Nr} \\
\text { próbki }\end{array}$} & \multicolumn{3}{|c|}{ Zawartość gazów, \% } & \multirow{2}{*}{ Uwagi } & \multirow{2}{*}{$\begin{array}{l}\text { Wynik pró- } \\
\text { by gięcia }\end{array}$} \\
\hline & $\mathrm{O}_{2}$ & $\mathrm{~N}_{2}$ & $\mathrm{H}_{2}$ & & \\
\hline 3 & 0,14 & 0,0180 & 0,0067 & $\begin{array}{l}\text { próbka poddana obróbce } \\
\text { cieplnej po spawaniu, śred- } \\
\text { nica spoiwa } 3,2^{*}\end{array}$ & negatywny \\
\hline 4 & 0,13 & 0,0141 & 0,0076 & $\begin{array}{l}\text { próbka bez obróbki cieplnej, } \\
\text { średnica spoiwa 3,2, spawa- } \\
\text { nie z nasadką przypalnikowa }\end{array}$ & pozytywny \\
\hline 5 & 0,14 & 0,0182 & 0,0072 & $\begin{array}{l}\text { próbka bez obróbki cieplnej, } \\
\text { średnica spoiwa } 2,4 \text {, spa- } \\
\text { wanie bez nasadki przypal- } \\
\text { nikowej }\end{array}$ & negatywny \\
\hline 6 & 0,12 & 0,0215 & 0,0052 & $\begin{array}{l}\text { próbka bez obróbki cieplnej, } \\
\text { średnica spoiwa } 3,2 \text {, spa- } \\
\text { wanie bez nasadki przypal- } \\
\text { nikowej }\end{array}$ & negatywny \\
\hline $\begin{array}{l}\text { Ti3401 } \\
\text { (gra- } \\
\text { de12) }\end{array}$ & $\begin{array}{c}0,08 \\
\div 0,16\end{array}$ & $\begin{array}{c}\max \\
0,0150\end{array}$ & $\begin{array}{c}\max \\
0,0080\end{array}$ & $\begin{array}{l}\text { dane wg PN-EN ISO } 24034 \\
{[32]}\end{array}$ & - \\
\hline
\end{tabular}

\section{Badanie składu chemicznego}

W celu określenia zgodności zakupionych materiałów z wymaganiami odpowiednich norm przedmiotowych przeprowadzono analize składu chemicznego z zastosowaniem pomiaru absorpcji promieniowania podczerwonego (HFIR) i fluorescencji rentgenowskiej (XRF). Wyniki badania przedstawiono w tablicy V.

Tablica V. Skład chemiczny materiałów podstawowych i stopiw Table V. Chemical composition of base materials and weld metals

\begin{tabular}{|c|c|c|c|c|c|c|}
\hline \multirow{2}{*}{$\begin{array}{c}\mathrm{Nr} \\
\text { próbki }\end{array}$} & \multicolumn{5}{|c|}{$\begin{array}{l}\text { Zawartość poszczególnych } \\
\text { pierwiastków, \% }\end{array}$} & \multirow[t]{2}{*}{ Uwagi } \\
\hline & $\mathrm{Ti}$ & $\mathrm{Fe}$ & $\mathrm{Ni}$ & Mo & C & \\
\hline 1 & reszta & 0,045 & 0,61 & 0,32 & 0,005 & $\begin{array}{l}\text { materiał podstawowy zakupio- } \\
\text { ny dodatkowo }\end{array}$ \\
\hline 2 & reszta & 0,056 & 0,74 & 0,34 & 0,009 & $\begin{array}{l}\text { materiał podstawowy zakupio- } \\
\text { ny do wykonania zlecenia }\end{array}$ \\
\hline $\begin{array}{c}\text { Ti3401 } \\
\text { (gra- } \\
\text { de12) } \\
\end{array}$ & $\begin{array}{c}\leq \\
97,725\end{array}$ & $\begin{array}{c}\max \\
0,3\end{array}$ & $0,6 \div 0,9$ & $0,2 \div 0,4$ & $\begin{array}{l}\max \\
0,08\end{array}$ & ASTM B265-10 \\
\hline 3 & reszta & 0,017 & 0,69 & 0,34 & 0,015 & $\begin{array}{l}\text { próbka poddana obróbce ciepl- } \\
\text { nej po spawaniu, średnica spo- } \\
\text { iwa } 3,2\end{array}$ \\
\hline 4 & reszta & 0,083 & 0,65 & 0,33 & 0,019 & $\begin{array}{l}\text { próbka bez obróbki cieplnej, } \\
\text { średnica spoiwa } 3,2 \text {, spawanie } \\
\text { z nasadką przypalnikową }\end{array}$ \\
\hline 5 & reszta & 0,112 & 0,66 & 0,34 & 0,017 & $\begin{array}{l}\text { próbka bez obróbki cieplnej, } \\
\text { średnica spoiwa } 2,4 \text {, spawa- } \\
\text { nie bez nasadki przypalnikowej }\end{array}$ \\
\hline 6 & reszta & 0,016 & 0,65 & 0,35 & 0,020 & $\begin{array}{l}\text { próbka bez obróbki cieplnej, } \\
\text { średnica spoiwa } 3,2 \text {, spawa- } \\
\text { nie bez nasadki przypalnikowej }\end{array}$ \\
\hline $\begin{array}{c}\text { Ti3401* } \\
\text { (gra- } \\
\text { de12) }\end{array}$ & $\begin{array}{c}\leq \\
97,725\end{array}$ & $\begin{array}{l}\max \\
0,15\end{array}$ & $0,6 \div 0,9$ & $0,2 \div 0,4$ & $\begin{array}{l}\max \\
0,03\end{array}$ & dane wg PN-EN ISO 24034 \\
\hline
\end{tabular}




\section{Analiza wyników badań}

Analiza składu chemicznego za pomocą metod HFIR oraz XRF wykazała różnice $\mathrm{w}$ zawartości poszczególnych pierwiastków stopowych, tj.: żelaza, węgla, niklu i molibdenu. Mieszczą się one w dopuszczalnych zawartościach, określonych w odpowiednich normach, zarówno dla blach, jak i stopiw (tabl. III, V). Pomiary zawartości gazów w materiale podstawowym wykazały, że ilość gazów jest wyższa niż podana w ateście materiałowym, natomiast zawartość tych gazów nie przekracza maksymalnej ilości dopuszczonej w normie ASTM B265-10. Badanie zawartości gazów w próbkach stopiwa 4 i 6 , wykonanych z zastosowaniem tego samego materiału dodatkowego (ten sam gatunek i średnica - 3,2 mm), lecz różniących się osłoną gazową, wykazało różnice w zawartości analizowanych gazów (głównie azotu). W próbce stopiwa 4, której próba gięcia dała wynik pozytywny, zawartość azotu była 1,5 razy mniejsza, natomiast zawartość tlenu o $0,01 \%$ i wodoru o $0,0024 \%$ wyższa niż w próbce 6 . W próbce 5 , której próba gięcia dała wynik negatywny, zawartość tlenu i azotu była wyższa niż w próbce 4 . Różnice w zawartościach gazów wynikają $z$ tego, że proces spawania prowadzono $w$ różnych warunkach technologicznych (tabl. IV). W próbce 5 zawartość gazów była niższa niż w próbce 6 . Spowodowane jest to mniejszym zaburzeniem osłony gazowej przez pręt spawalniczy oraz niższymi parametrami prądowo-napięciowymi.

Przeprowadzenie obróbki cieplnej w atmosferze powietrza, w celu obniżenia zawartości gazów, jest skuteczne jedynie w przypadku wodoru. Badania zawartości gazów w próbce 3, poddanej procesowi obróbki cieplnej po spawaniu, wykazały, że ilość tlenu nieznacznie się zwiększyła, część wodoru wydyfundowała, a ilość azotu uległa znacznemu zwiększeniu, w porównaniu z próbką 4 , która została wykonana z zastosowaniem tej samej technologii spawania, ale nie została podana obróbce cieplnej po spawaniu. Zawartość tlenu i azotu w blachach lub stopiwie $z$ tytanu jest wynikiem oddziaływania temperatury, czasu oraz atmosfery, w jakiej wykonywana jest obróbka. Wraz ze wzrostem czasu i temperatury wzrasta zawartość azotu i tlenu. $Z$ tego powodu nie zaleca się obróbki cieplnej stopu tytanu grade $12 \mathrm{w}$ atmosferze powietrza.

W przypadku wyżarzania odprężającego w temperaturze powyżej $427^{\circ} \mathrm{C}$, obróbkę cieplną należy prowadzić w piecach z atmosferą kontrolowaną - pozbawioną azotu i tlenu (np. argonu). W przypadku stopu tytanu grade 12 temperatura odprężania wynosi $480 \div 595^{\circ} \mathrm{C}$, a czas obróbki $0,25 \div 4 \mathrm{~h}$. Zaleca się, aby podczas obróbki cieplnej stosować górne zakresy temperatury i krótkie czasy wygrzewania $[1 \div 3]$. Badania wykazały, że różnice w zawartości azotu i tlenu mogą wynikać $z$ zaburzeń w osłonie łuku. Różnica w zawartości wodoru mogła wynikać $z$ wilgoci, pochodzić od węglowodorów znajdujących się na powierzchni spoiwa lub materiału podstawowego, czy też z zanieczyszczonych związkami organicznymi rękawic spawacza.
Obniżenie zawartości wodoru może też być wywołane przez zastosowanie obróbki cieplnej. Na zawartość gazów wpływa również technologia spawania. Zastosowanie zbyt wysokich parametrów prądowo-napięciowych może spowodować przegrzanie złącza. Im wyższy stopień przegrzania próbki, tym większa zawartość gazów w spoinie i gorsze właściwości plastyczne. Zawartość gazów w próbkach stopiwa była niższa niż dopuszczalna zawartość dla materiału podstawowego. Pomimo niższych zawartości gazów próby gięcia zakończyły się wynikiem negatywnym. Wynika z tego, że ze względu na strukturę spoiny, dopuszczalna zawartość azotu, wodoru i tlenu w spoinie jest bardziej ograniczona niż dla materiału podstawowego. W związku z tym należy tak dobrać technologię spawania, aby zawartość tych gazów była jak najmniejsza.

\section{Źródła tlenu, azotu i wodoru. Zapobieganie przedostawaniu się gazów do jeziorka spawalniczego}

Gazy takie jak tlen czy azot przedostają się do jeziorka ciekłego metalu głównie z powietrza otaczającego miejsce spawania, co jest związane $z$ niedostateczną osłoną gazową podczas spawania. Aby zabezpieczyć to miejsce przed dostępem powietrza, należy stosować dysze o odpowiedniej średnicy z dyfuzorami oraz dobrać odpowiedni przepływ gazu osłonowego, tak aby uzyskać przepływ laminarny (rys. 7). Można również zastosować nasadki przypalnikowe, jeżeli sama dysza nie wystarcza, aby odpowiednio osłonić lico. Do osłony grani należy stosować podkładki formujące, aby ją zabezpieczyć przed dostępem powietrza. Jako gaz osłonowy należy stosować czysty argon.

Detale o niewielkich gabarytach można spawać w komorach wypełnionych argonem. Zapewnia to uzyskanie spoin wysokiej jakości bez jakichkolwiek przebarwień. Podczas spawania elementów z tytanu w komorze ochronnej z komory należy całkowicie wyprzeć powietrze przez argon. Nie wolno „wypalać” resztek tlenu, ponieważ w wyniku spalania powstaje dwutlenek węgla, który podczas spawania może być rozkładany w łuku na tlen i tlenek węgla, ponadto samo spalanie nie spowoduje usunięcia szkodliwego azotu. Podczas spawania w komorze należy dokonywać pomiarów nie tylko tlenu, ale również azotu, których zawartość po-

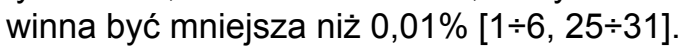

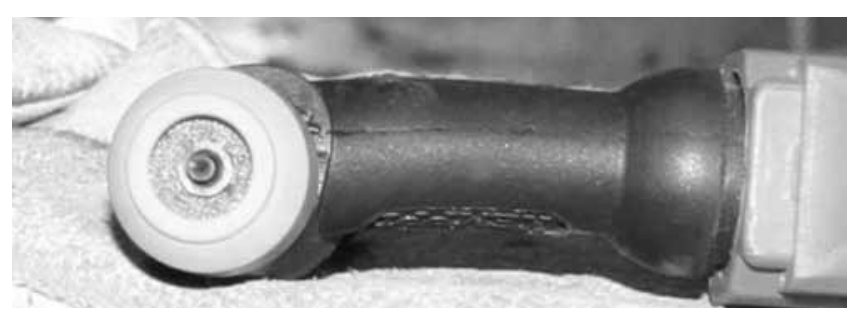

Rys. 7. Dysza gazowa z dyfuzorem

Fig. 7. Gas nozzle with diffuser 
Bezpośrednim źródłem tlenu i azotu może być również utleniona i naazotowana powierzchnia spoiwa (rys. 8). Spoiwo do spawania tytanu powinno być pozbawione jakichkolwiek przebarwień i nalotów. Po zakończeniu spawania, a przed rozpoczęciem układania kolejnego ściegu, końcówkę spoiwa należy odciąć w celu uniknięcia niezgodności (rys. 8) [19].

Podczas stosowania podkładek z gazem formującym należy zapewnić ścisłe przyleganie podkładki do blachy, by uniknąć utlenienia czy naazotowania grani (rys. 9). Pozostawienie nieszczelności powoduje zasysanie powietrza do komory $z$ gazem osłonowym i powstanie niepożądanych warstw nalotowych (rys. 10).

Wlot gazu osłonowego do podkładki formującej powinien być umieszczony od strony rozpoczęcia spawania, natomiast podkładka powinna zawierać
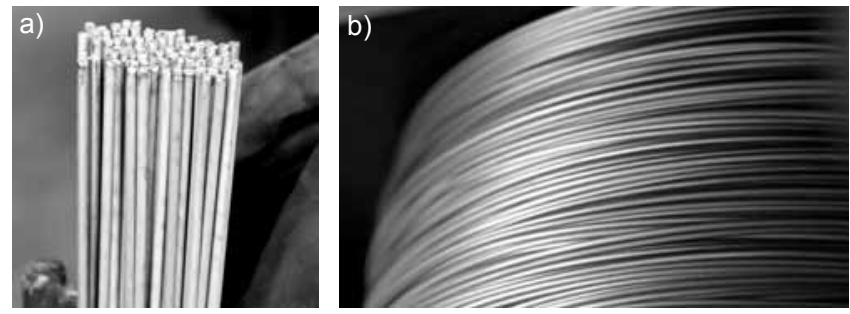

c)

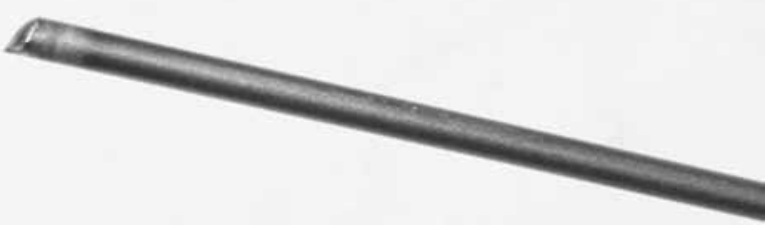

Rys. 8. Materiały dodatkowe: a) utlenione pręty do spawania ręcznego metodą TIG, b) utleniony drut do spawania półautomatycznego metoda TIG, c) utleniona końcówka pręta po przerwaniu spawania Fig. 8. Filler materials: a) oxidized rod for TIG hand welding, b) oxidized wire for semi-automatic TIG welding, c) oxidized ending of rod after welding

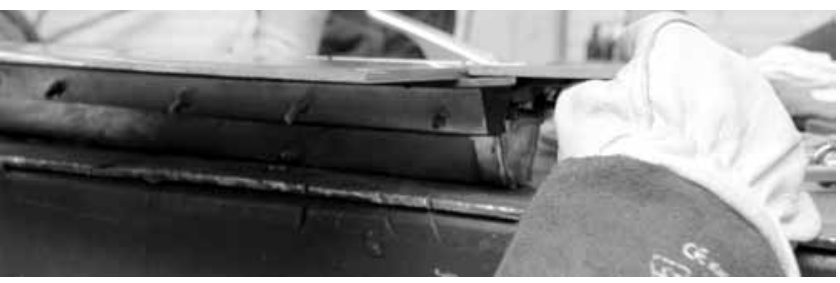

Rys. 9. Niepełne przyleganie podkładki osłaniającej grań Fig. 9. Incorrect adhere of backing bar

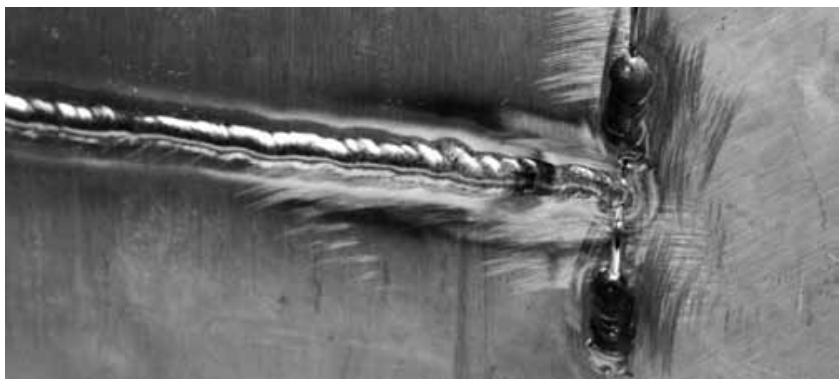

Rys. 10. Grań spoiny złącza próbnego. Widoczny efekt niewłaściwego przylegania podkładki i niewłaściwego kierunku podawania gazu od strony grani

Fig. 10. The root of the sample welded joint. Visible incorrect adhere of backing bar and direction of gas supply in the root side of the weld miejsce swobodnego wypływu gazu z komory osłonowej po stronie przeciwnej. Natężenie przepływu gazu

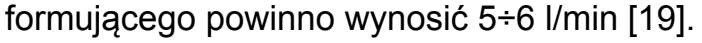

W przypadku spawania wielościegowego każdy kolejny ścieg należy przeszczotkować w celu usunięcia powstałych cienkich warstewek tlenków i azotków. Pozostawienie tlenków i azotków zwiększa ryzyko powstania przyklejeń, $z$ uwagi na wysoką temperaturę topnienia tych związków. Zawartość wodoru można ograniczyć przez zapewnienie odpowiednich warunków przechowywania materiałów dodatkowych oraz czystości powierzchni spoiw (rys. 8). Barwy nalotowe znajdujące się na spoiwie, a w szczególności biały nalot, należy usunąć przed spawaniem za pomocą trawienia chemicznego lub papierów ściernych. Nie można stosować spoiw mających na powierzchni barwy nalotowe.

Podczas spawania ogromny wpływ na właściwości złączy wywiera ilość wprowadzonego ciepła oraz temperatura międzyściegowa. Przekroczenie ustalonych parametrów powoduje spadek właściwości plastycznych i udarności. W przypadku spawania tytanu grade 12 metodą TIG, elektrodą wolframową torowaną o średnicy $3,2 \mathrm{~mm}$ i spoiwem o średnicy $3,2 \mathrm{~mm}$, ilość wprowadzonego ciepła nie powinna przekraczać

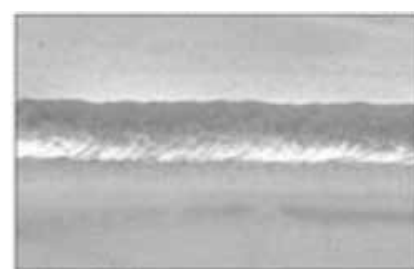

Srebrny

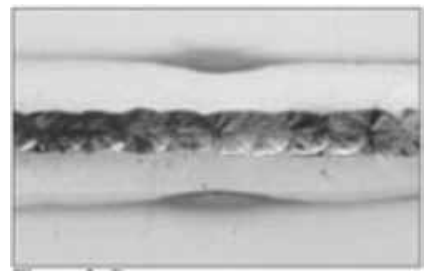

Brązowy

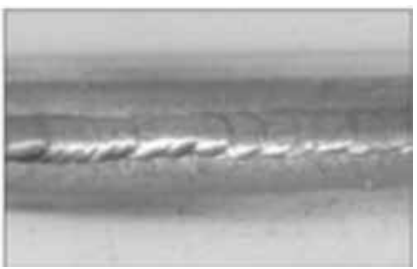

Jasnoniebieski

Matowy łososioworóżowy

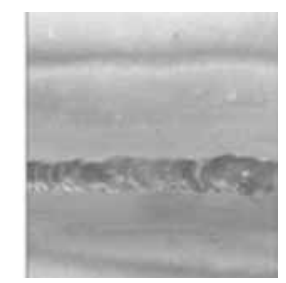

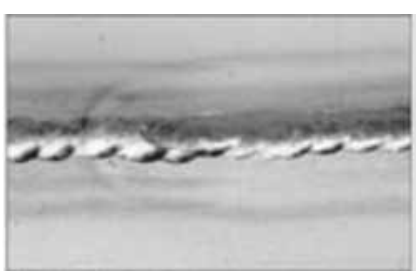

Słomkowy

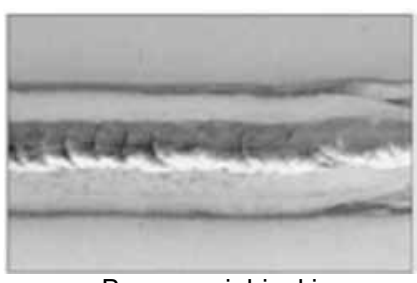

Brązowoniebieski

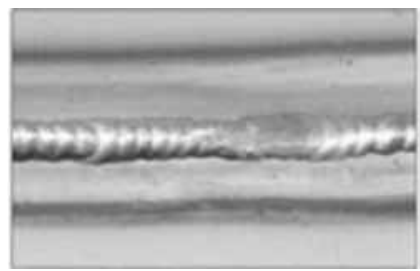

Zielononiebieski

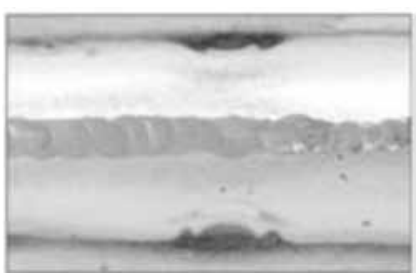

Białe matowe tlenki
Rys. 11. Przykłady barw nalotowych powstających na powierzchni złącza spawanego $[5,19]$

Fig. 11. Examples of heat tint on the surface of welded joint $[5,19]$ 
$1,2 \mathrm{~kJ} / \mathrm{mm}$. Takie parametry spawania umożliwiają uzyskanie spoin o odpowiednich właściwościach [1, 2, 5, 19]. W przypadku mniejszych średnic spoiwa i elektrod należy wprowadzać mniej ciepła. Temperatura międzyściegowa nie powinna przekraczać $100^{\circ} \mathrm{C}$.

Na rysunku 11 przedstawiono przykładowe barwy nalotowe powstałe na powierzchni złącza spawanego; kolory jasnosrebrny, srebrny, słomkowy czy brązowy są akceptowane, natomiast pozostałe, tj.: fioletowy, niebieski (jasny i ciemny), zielony, szary (matowy) i biały są nieakceptowane.

W szczególnych przypadkach, gdy wymagana jest bardzo wysoka odporność korozyjna, kolor słomkowy nie jest dopuszczalny $[5,19]$.

\section{Podsumowanie}

Technologia spawania tytanu jest uzależniona od jego właściwości, a zwłaszcza wysokiej reaktywności z gazami znajdującymi się w powietrzu i niskiej przewodności cieplnej. Wysokie powinowactwo do tlenu, azotu oraz wysoka rozpuszczalność wodoru sprawiają, że podczas spawania tytanu należy zachować szczególną ostrożność i reżim technologiczny. Miejsce spawania powinno być dodatkowo osłonięte od przeciągów. Złącze spawane powinno być w możliwie najlepszy sposób chronione gazem osłonowym, w tym od strony grani powinny być stosowane podkładki formujące.
Narzędzia do pracy z tytanem powinny być wolne od zanieczyszczeń smarami lub olejami oraz nie powinny mieć kontaktu ze stalą węglową. W przypadku stosowania przyrządów wykonanych ze stali, na ich końcówkach należy umieszczać tytanowe podkładki.

Zachowanie odpowiedniej technologii spawania, wolnych od zanieczyszczeń materiałów podstawowych i dodatkowych, oraz osłon ciekłego, jak również gorącego metalu zapewnia uzyskanie spoin wysokiej jakości o wymaganych właściwościach plastycznych i wytrzymałościowych oraz odporności korozyjnej.

\section{Literatura}

[1] Matthew J. Donachie, Jr.: Titanium. A Technical Guide. ASM International, United States of America, 2000.

[2] C. Leyens, M. Peters: Titanium and Titanium Alloys. Fundamental Applications. Wiley - VCH GmbH \& Co. KGaA, Weinheim, 2003.

[3] G. Lutjering, J.C. Williams: Titanium. Springer - Verlag Berlin Heidelberg New York, 2003.

[4] R. Boyer, G. Welsch, E.W. Collings: Materials Properties Handbook: Titanium Alloys, ASM International, USA, 2007.

[5] L.S. Smith, P. Threadgill, M. Gittos: Welding Titanium a Designers and Users Handbook, TWI, United Kingdom, 1999.

[6] K. Tubielewicz, A. Zaborski: Specyfika łączenia (spawania) stopów tytanu, Technologia i Automatyzacja Montażu, $\mathrm{nr} 3 / 2007$

[7] http://www.mhi.co.jp

[8] http://leosztitanium.en.busytrade.com.

[9] http://www.sunrines.com.

[10] http://www.titanmf.com/products/.

[11] http://www.mingchenchina.com.

[12] http://www.porscheboost.com.

[13] http://www.medicalexpo.com.

[14] http://www.trimet.com.tr.

[15] http://www.biohexagon.com.

[16] http:// http://www.goldcommerce.pl.

[17] http://www.klugex.com.

[18] http://www.pakamera.pl.

[19] Titanium Alloy Guide - RMI Titanium Company.

[20] ASTM B265-10 Titanium and Titanium Alloy Strip, Sheet, Plate.

[21] 15614-5 Specyfikacja i kwalifikowanie technologii spawania metali - Badanie technologii spawania - Część 5: Spawanie łukowe tytanu, cyrkonu i ich stopów.

[22] PN-EN 485-2: 2007 Aluminium i stopy aluminium - Blachy, taśmy, płyty - Część 2: Właściwości mechaniczne.

[23] PN-EN 10088-1 Stale odporne na korozję - Część 1: Gatunki stali odpornych na korozję.
[24] PN-EN 10088-2 Stale odporne na korozję - Część 2: Warunki techniczne dostawy blach i taśm ze stali nierdzewnych ogólnego przeznaczenia.

[25] A. Agüero, J.M. Albella, M.P. Hierro, J. Phillibert and F.J. Pérez Trujillo: Influence of Beta Stability on Hydrogen Diffusion in Various Beta Titanium Alloys, Defect and Diffusion Forum (Vol. 289-292), 2009., s. 87-94.

[26] I. M. Pohrelyuk, V. M. Fedirko and V. M. Dovhunyk: Influence of nitriding and oxidation on the wear of titanium alloys, Materials Science, Vol. 36, Nr 3/2000, 466-471.

[27] M. B. Ivanov, S. S. Manokhin, Y. R. Kolobov, D. A. Nechayenko: Phase Composition and Microstructure of Ti-6Al-4V Alloy a Hydrogen-Plastic Working, Materials Physics and Mechanics Nr 10/2010, 62-71.

[28] P. Perez: Influence of nitriding on the oxidation behaviour of titanium aloys AT $700^{\circ} \mathrm{C}$, Surface and Coatings Technology, Vol. 191, Nr 2-3/2005, s. 293-302.

[29] A. M. Chaze, C. Coddet: Influence of alloying elements on the dissolution of oxygen in the metallic phase during the oxidation of titanium alloys, Journal of Materials Science, Vol. 22, $\mathrm{Nr} 4$, s. 1206-1214.

[30] N.E. Paton, J.C. Williams: Effect of hydrogen on titanium and its alloys, Hydrogen in metals; Proceedings of the International Conference on the Effects of Hydrogen on Materials Properties and Selection and Structural Design, Champion, United States; 1973. s. 409-431.

[31] F.H. Froes, O.N. Senkov, J.I. Qazi: Hydrogen as a temporary alloying element in titanium alloys: thermohydrogen processing, International Materials Reviews, Vol. 49, Nr 3-4, June 2004, s. 227-245.

[32] PN-EN ISO 24034 Materiały dodatkowe do spawania - Druty i pręty lite do spawania tytanu i stopów tytanu - Klasyfikacja.

[33] PN-EN ISO 6847:2005 Materiały dodatkowe do spawania - Wykonanie stopiwa do analizy składu chemicznego. 